\title{
Comparison of pupil diameter and tear production in dogs treated with acepromazine, tramadol and their combination ${ }^{1}$
}

Paulo Henrique de Albuquerque Santos ${ }^{2}$, Kelly Cristine de Sousa Pontes ${ }^{3}$, Rogério Pinto ${ }^{3}$, Paula Baêta da Silva Rios ${ }^{4}$, Gláucia Matos Marques da Silva , Andréa Pacheco Batista Borges ${ }^{5}$, Lukiya Silva Campos Favarato

\begin{abstract}
Some ophthalmic surgeries require induction of mydriasis, however, drugs traditionally used for this purpose significantly reduces tear production. To evaluate the effect of acepromazine and tramadol, used alone or in combination, on pupil diameter, tear production, heart and respiratory rate, systolic blood pressure and rectal temperature, these drugs were administered to seven clinically normal dogs divided into three experimental groups (G1 - acepromazine; G2 - tramadol; G3 - tramadol + acepromazine) that differed only in the sedation protocol. Parameters were measured in four experimental moments. Miosis occurred in G1, in addition to reduced tear production and respiratory rate. No significant changes were found in the parameters assessed in G2, whereas in G3, there was decrease in tear production of the right eye, decrease in the respiratory rate and rectal temperature. Tramadol proved to be a drug suitable for pre-anesthetic procedures that require the maintenance of pupil diameter and keeps the tear production within normal parameters. However, the use of acepromazine alone or in combination with tramadol requires protection of the patient's eye surface to prevent the occurrence of undesirable ophthalmic changes.
\end{abstract}

Key words: phenothiazines, mydriasis, Schirmer tear test, opioids.

\section{RESUMO}

\section{Diâmetro pupilar e produção lacrimal comparados em cães tratados com acepromazina, tramadol e sua associação}

Alguns procedimentos cirúrgicos oftálmicos requerem a obtenção de midríase, entretanto, os fármacos tradicionalmente utilizados com esta finalidade reduzem significativamente a produção lacrimal. Com o objetivo de verificar o efeito da acepromazina e do tramadol, utilizados isoladamente, ou em conjunto, sobre o diâmetro pupilar, a produção lacrimal, as frequências cardíaca e respiratória, a pressão arterial sistólica e a temperatura retal, esses fármacos foram administrados em sete cães clinicamente normais, que integraram três grupos experimentais (G1 - acepromazina; G2 tramadol; G3 - acepromazina + tramadol), diferenciando-se apenas quanto ao protocolo tranquilizante utilizado. Os parâmetros foram mensurados em quatro momentos experimentais. Houve miose no G1, além da redução da produção lacrimal e da frequência respiratória. Verificou-se que, no G2, não houve alterações significativas nos parâmetros avaliados e, no G3, verificou-se a diminuição da produção lacrimal do olho direito, da frequência respiratória e da

\footnotetext{
Received: 26/12/2012; Accepted: 25/01/2013.

${ }^{1}$ Article extracted from the Degree Final Dissertation of the Veterinary Medicine course.

'Veterinary Surgeon. Departamento de Veterinária, Faculdade de Ciências Biológicas e da Saúde FACISA/UNIVIÇOSA, Avenida Maria de Paula Santana, 3815, 36570-000, Viçosa, Minas Gerais, Brazil. veterinariopaulohenrique@yahoo.com.br

${ }^{3}$ Veterinary Surgeon, Doctor of Science. Departamento de Veterinária, Faculdade de Ciências Biológicas e da Saúde FACISA/UNIVIÇOSA, Avenida Maria de Paula Santana, 3815, 36570-000, Viçosa, Minas Gerais, Brazil. kellycpontes@yahoo.com.br (corresponding author); zootecnistarpinto@gmail.com

${ }^{4}$ Undergraduates in Veterinary Medicine. Departamento de Veterinária, Faculdade de Ciências Biológicas e da Saúde FACISA/UNIVIÇOSA, Avenida Maria de Paula Santana, 3815, 36570-000, Viçosa, Minas Gerais, Brazil. paulabaeta@yahoo.com.br; ninha.an@hotmail.com

${ }^{5}$ Veterinary Surgeons, Doctors of Science. Departamento de Veterinária, Universidade Federal de Viçosa, Campus Viçosa, Avenida Peter Henry Rolfs, s/n, 36570-000, Viçosa, Minas Gerais, Brazil. andreia@ufv.br; 1scampos@ufv.br
} 
temperatura retal. $\mathrm{O}$ tramadol demonstra ser um fármaco pré-anestésico adequado para procedimentos que necessitem da manutenção do diâmetro pupilar e mantém a produção lacrimal dentro dos parâmetros normais. Entretanto, com o uso da acepromazina isolada ou associada ao tramadol, torna-se necessário proteger a superfície ocular do paciente com a finalidade de se evitar a ocorrência de alterações oftálmicas indesejáveis.

Palavras-chave: fenotiazinas, midríase, teste lacrimal de Schirmer, opioides.

\section{INTRODUCTION}

In veterinary medicine, general anesthesia is used for all intraocular surgical procedures (Slatter \& Colitz 2007), including those for cataract extraction in which the maintenance of mydriasis is critical, since pupil constriction may result in serious complications during the procedure (Gross \& Giuliano, 2007; Almeida et al., 2008). However, most of anesthetics induce miosis (Bechara, 2002; Slatter, 2005a; Gross \& Giuliano, 2007) and reduction of tear production, thus requiring corneal lubrication during these anesthesia procedures (Krupin et al., 1977; Brightman et al. 1983; Herring et al. 2000; Pontes et al. 2010).

Neuroleptoanalgesia (NLA) is commonly used in veterinary medicine as a pre-anesthetic agent to provide analgesia in minor surgical procedures. Phenothiazines and opioids have been extensively used to produce NLA. When used in combination, they promote sedation and analgesia, resulting in better effects in comparison with their isolated use (Monteiro et al. 2009).

The iris is a diaphragm that divides the eyeball into two chambers, an anterior and a posterior. Its central opening is called the pupil (Coulter \& Schmidt, 1996). The iris muscles of mammals are smooth muscles. The sphincter muscle or iris constrictor, has muscarinic cholinergic receptors under parasympathetic control which, when activated, results in miosis. In contrast, the iris dilator muscle has $\alpha_{1}$-adrenergic receptors innervated by sympathetic branches accompanying the ciliary nerve (the ophthalmic branch of the trigeminal nerve) (Coulter \& Schmidt, 1996; Gross \& Giuliano, 2007; Wilkie, 2007). The drugs produce mydriasis by paralysis of the sphincter muscle and the stimulation of the iris dilator muscle (Moore, 2003; Gross \& Giuliano, 2007), such as anticholinergics (Wilkie, 2007) and adrenergic agonists, when administered topically (Slatter, 2005a). However, lacrimal secretions are reduced after prolonged topical administration of atropine and may intensify the signs of tear deficiency (Moore, 2003; Pigatto et al., 2007) such as hypertonicity of the remaining tear film, dehydration of the epithelium of the conjunctiva and cornea, hypoxia of the corneal epithelium and stroma, secondary inflammation of the ocular surface, and the formation of corneal ulcers (Slatter, 2005b).

The Schirmer tear test (STT) is a semiquantitative method of measuring tear production. It is performed with sterile absorbent paper strips, packed in pairs, notched at $5 \mathrm{~mm}$ from its end. Each strip is folded and placed in that slot in the lateral third of the lower eyelid fornix for one minute (Slatter, 2005c). The test was developed according to two different techniques (Gelatt et al. 1975). The STT1 measures the production of basal and reflex tears and is the most routinely used. The STT2 evaluates tear production after application of topical anesthetic on the cornea (Slatter, 2005c) and in animals which cannot be assessed by the STT1 or with corneal injury (Saito \& Kotani, 2001).

The values measured by STT1 may vary with environmental conditions. In normal dogs, the average value varies from $17.01 \pm 4.28 \mathrm{~mm} / \mathrm{min}$ (Laus et al., 1995) to $21 \pm 4.2 \mathrm{~mm} / \mathrm{min}$ (Gelatt et al., 1975).

Tramadol hydrochloride is a synthetic partial opioid agonist with low affinity for $\mu$ receptors and analgesic potency compared to one tenth of morphine. Its effectiveness is limited compared to full agonists, since partial agonists may not involve all types of opioid receptors (Branson \& Gross, 2003).

Opioids have different effects on pupil diameter in different species. In general, they tend to produce mydriasis in cats, rats and monkeys and miosis in dogs, rabbits and humans (Lamont \& Mathews, 2007). However, tramadol does not significantly alter the human pupil diameter (Knaggs et al., 2004).

Parrilha et al. (2009) reported that tramadol does not significantly alter the cardiovascular, respiratory and thermoregulatory parameters of dogs.

The most used phenothiazine derivative as premedication in veterinary medicine is acepromazine (Gross, 2003; Lemke, 2007). Phenothiazines promote light 
sedation, though without disconnecting the animal from the environment, as they block the dopamine effects. These drugs do not promote analgesia, but potentiate the action of analgesics (Cortopassi \& Fantoni, 2002, Gross, 2003). Their main hemodynamic effect is blood hypotension, resulting from blockage of peripheral $\alpha_{1}$ adrenergic receptors. Other effects reported in dogs are decrease of rectal temperature and respiratory rate by decreasing the sensitivity of chemoreceptors to carbon dioxide (Cortopassi \& Fantoni, 2002; Gross, 2003; Lemke, 2007).

In cats, the administration of acepromazine promotes the reduction of tear production measured by STT1 (Ghaffari et al., 2010).

The acepromazine tramadol combination causes slight reduction in heart and respiratory rate, systolic blood pressure and rectal temperature in dogs (Monteiro et al., 2009).

This study was conducted to evaluate and compare quantitatively tear production, as well as possible variations in pupil diameter and changes in heart and respiratory rate, systolic blood pressure and body temperature in $\operatorname{dog}$ s treated with these drugs, alone and in combination.

\section{MATERIAL AND METHODS}

This experiment was approved by the Ethics Committee in Research of the Faculty of Biological Sciences and Health - FACISA / UNIVIÇOSA, number 00040/2011-I. Seven healthy adult dogs, breed, age estimated from 2 to 10 years of age and mean weight of $18.87 \mathrm{~kg}$, from the kennel of the Department of Veterinary - UNIVIÇOSA. These animals were previously submitted to clinical, laboratory, and ophthalmic examination to exclude possible carriers of alterations that could interfere with the results.

The seven dogs underwent three stages of premedication (MPA). Initially they were sedated with acepromazine (1\% Acepram ${ }^{\circledR}$ ) and named group 1 (G1). After seven days they were subjected to a second stage, where they received premedication with tramadol (Tramal (B 5\%) and were named group $2(\mathrm{G} 2)$. After seven days, they received combination of tramadol and acepromazine and were called Group 3 (G3). Thus, seven dogs integrated three groups that differed only in the protocol of preanesthetic medication, using the same animals for each group. A seven day interval between groups was given in order to meet the drug clearance time of and full recovery of the animals.

A closed room with controlled light and ambient temperature and humidity was used for the experiment. The animals went through a 20 minute period of adaptation to the environment before performing the experimental procedures.

The drugs were administered intramuscularly (IM) in the region of the semitendinosus and semimembranosus muscles of the right hindlimb of each animal, at doses of $0.1 \mathrm{mg} / \mathrm{kg}$ in G1 (acepromazine); $2 \mathrm{mg} / \mathrm{kg}$ in G2 (tramadol); and 0.1 to $2 \mathrm{mg} / \mathrm{kg}$ in G3 (acepromazine and tramadol, respectively). In each animal, the parameters were measured $15 \mathrm{~min}$ before and 15, 30 and $45 \mathrm{~min}$ after drug administration, totaling 60 minutes of experimental evaluation.

The pupil diameter (PD) was measured with a caliper, read in millimeters (Nikeghbali et al. 2007; Almeida et al. 2008), manually adjusted according to the pupil diameter (Figure 1A) oriented parallel to the corneal surface of the right eye of each animal, but without touching it (Figure 1 B). The evaluator stood in front of the animal, so that the dog's eyes were kept parallel to the table. Because of the
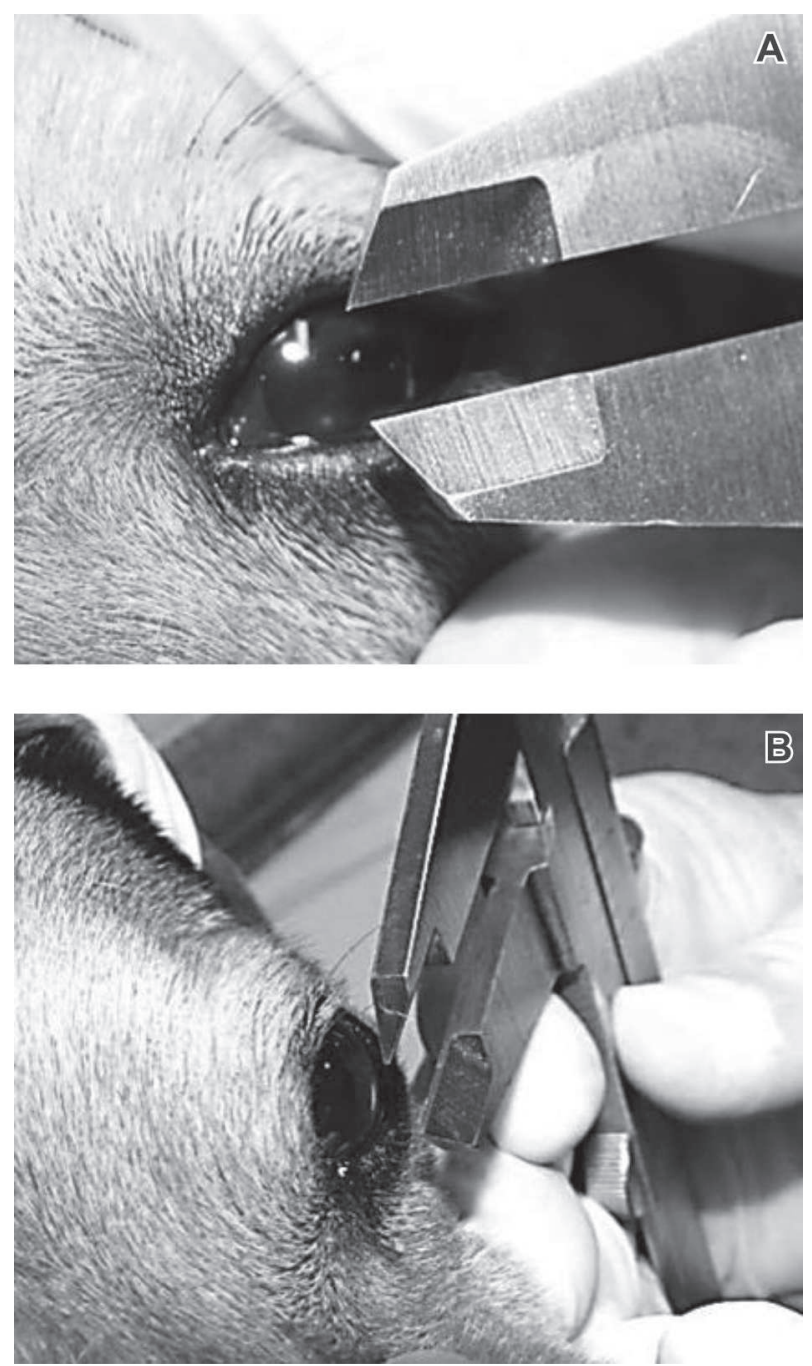

Figure 1. Measuring the pupil diameter in a dog at one of the experimental times. (A) Note the manual adjustment of the caliper to the pupil diameter; (B) Position of the caliper before the cornea without touching it. 
constant fluctuations in pupil diameter, three consecutive measurements were carried out and disparities between the values measured were recorded.

The tear production was measured by the STT1. The animals were kept on station or in sternal recumbency, according to their degree of sedation. A sterile Schirmer strip was folded into the slot at its end, still in the package, and placed into the lower conjunctival fornix of the right eye (STT-RE) of the dog (Figure 2) for one minute. During this time, the eyelids of the eye examined remained closed. Then, the same procedure was performed on the left eye (STT-LE), using a new sterile strip (Slatter, 2005c; Pontes et al., 2010).

Heart rate (HR) was measured by chest auscultation, using a stethoscope to count clinical beats per minute (bpm). The respiratory rate (RR) was measured by observing the chest and counting of inspiratory

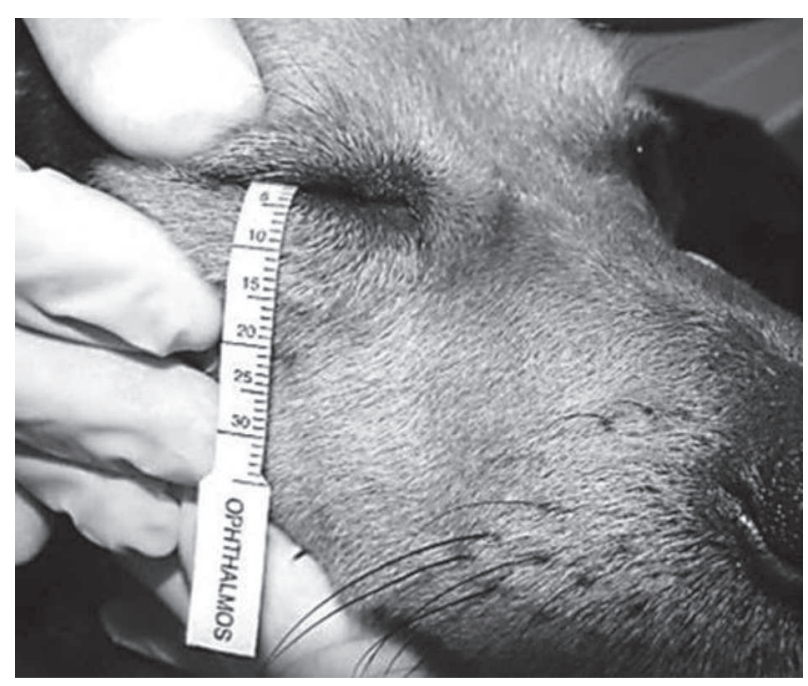

Figure 2. STT1 test in a dog at one of the experimental times. Note the test strip inserted in the medial portion of the lower eyelid. movements per minute (mpm). Systolic blood pressure (SBP) was measured by the Doppler method, using a mercury manometer and a veterinary doppler apparatus to measure the noninvasive blood pressure (Camacho \& Mucha, 2004) read in millimeters of mercury (mmHg). Rectal temperature (RT) was measured in degrees Celsius $\left({ }^{\circ} \mathrm{C}\right)$ with a digital clinical thermometer lubricated at its end and placed on the anal sphincter of the dog (Feitosa, 2004).

Data were examined by analysis of variance (ANOVA) and, if significant, by the Tukey test, at the maximum of $10 \%$ probability, using the software Statistical Analysis System (SAEG, 2007) of the Federal University of Viçosa. The effect of drugs on the parameters, over time, was analyzed by regression analysis for the biological interpretation of the results.

\section{RESULTS AND DISCUSSION}

The pupil diameters (PD) in G2 were higher than in G1 and G3, which were not significantly different (Table 1). There was a linear decrease of $0.0046 \mathrm{~mm} / \mathrm{min}$ in G1. But, there were no significant changes in the PD of G2 (Figure 3).

Thus, there was occurrence of miosis in the groups treated with acepromazine, even in combination with tramadol. The same result was observed by Knaggs et al. (2004) in a study wherein tramadol did not change the PD in human patients. According to Branson \& Gross (2003) and Duthie (2008), tramadol does not bind to all kinds of receptors like other opioids, which may be reason why it does not change the PD, unlike the total opioid agonists.

The values of the Schirmer Test for the right eye (STTRE) in G3 were lower than those observed in G1 and G2 (Table 1). There was a linear decrease in $\mathrm{G} 1$ and $\mathrm{G} 3$, with a reduction of 0.0967 and $0.1472 \mathrm{~mm} / \mathrm{min}$, respectively, over the experimental period (Figure 4).

Table 1. Means of the studied variables of the three groups (G1 - acepromazine; G2 - tramadol; and G3 - tramadol + acepromazine) compared by the Tukey test $(\mathrm{p}<0.10)$, standard deviation and significance level of interactions between treatments

\begin{tabular}{lccccccc}
\hline Group & $\begin{array}{c}\text { PD } \\
(\mathbf{m m})\end{array}$ & $\begin{array}{c}\text { STT-RE } \\
(\mathbf{m m} / \mathbf{m i n})\end{array}$ & $\begin{array}{c}\text { STT-LE } \\
(\mathbf{m m} / \mathbf{m i n})\end{array}$ & $\begin{array}{c}\text { HR } \\
(\mathbf{b p m})\end{array}$ & $\begin{array}{c}\text { RR } \\
(\mathbf{m p m})\end{array}$ & $\begin{array}{c}\text { RT } \\
\left({ }^{\circ} \mathbf{C}\right)\end{array}$ & $\begin{array}{c}\text { SBP } \\
(\mathbf{m m H g})\end{array}$ \\
\hline \multirow{2}{*}{$\mathrm{G} 1$} & $0.55 \mathrm{~B}$ & $20.96 \mathrm{~A}$ & $20.42 \mathrm{~A}$ & $107.64 \mathrm{AB}$ & $25.85 \mathrm{AB}$ & $38.64 \mathrm{AB}$ & $144.64 \mathrm{AB}$ \\
& \pm 0.16 & \pm 5.35 & \pm 5.18 & \pm 22.77 & \pm 11.09 & \pm 1.05 & \pm 46.26 \\
$\mathrm{G} 2$ & $0.66 \mathrm{~A}$ & $20.57 \mathrm{~A}$ & $20.39 \mathrm{~A}$ & $104.39 \mathrm{~B}$ & $31.03 \mathrm{~A}$ & $38.72 \mathrm{~A}$ & $159.64 \mathrm{~A}$ \\
& \pm 0.12 & \pm 5.27 & \pm 4.2 & \pm 11.82 & \pm 21.46 & \pm 0.42 & \pm 36.51 \\
$\mathrm{G} 3$ & $0.54 \mathrm{~B}$ & $14.32 \mathrm{~B}$ & $16.17 \mathrm{~B}$ & $118.32 \mathrm{~A}$ & $18.42 \mathrm{~B}$ & $38.27 \mathrm{~B}$ & $133.92 \mathrm{~B}$ \\
& \pm 0.15 & \pm 5.69 & \pm 5.38 & \pm 24.65 & \pm 7.51 & \pm 0.56 & \pm 31.95 \\
\hline $\mathrm{CV}(\%)$ & 24.04 & 27.64 & 25.80 & 19.39 & 59.81 & 1.84 & 27.59 \\
\hline \multicolumn{7}{c}{ Significance levels $(\%)$} \\
\hline
\end{tabular}

Means followed by the same letter in the same column are not significantly different.

$\mathrm{PD}=$ pupil diameter; STT-RE $=$ Schirmer tear test - right eye; STT-LE $=$ Schirmer tear test - left eye; HR = heart rate; RR = respiratory rate; $\mathrm{RT}=$ rectal temperature; $\mathrm{SBP}=$ systolic blood pressure. 
In $\mathrm{G} 3$, the times 30 and 45 min after drug administration showed tear production below the lower limit established by Laus et al. (1995) (Figure 4), demonstrating that the acepromazine tramadol combination causes considerable dryness of the cornea. In G2, there were no significant differences over time.

Tear production of the left eye (STT-LE) in G3 was lower than in G1 and G2 (Table 1). However, only G1 showed linear effect, with reduction of $0.0969 \mathrm{~mm} / \mathrm{min}$ (Figure 5).

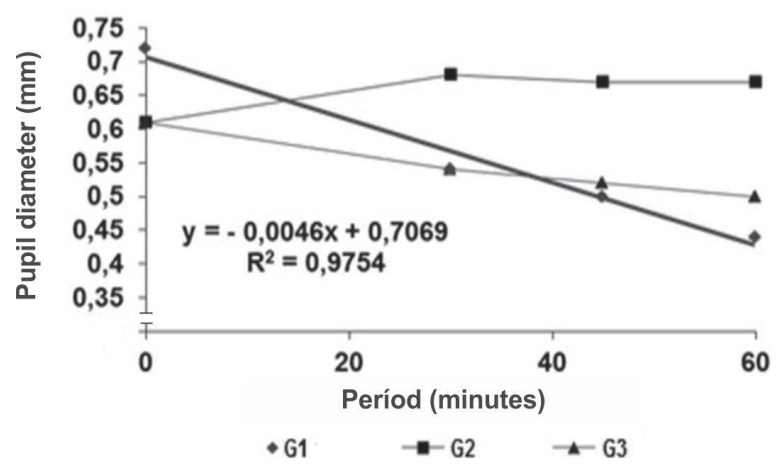

Figure 3. Decreasing linear effect on pupil diameter in G1 (acepromazine) with its respective equation over the experimental period. Groups G2 and G3 showed no significant linear effect.

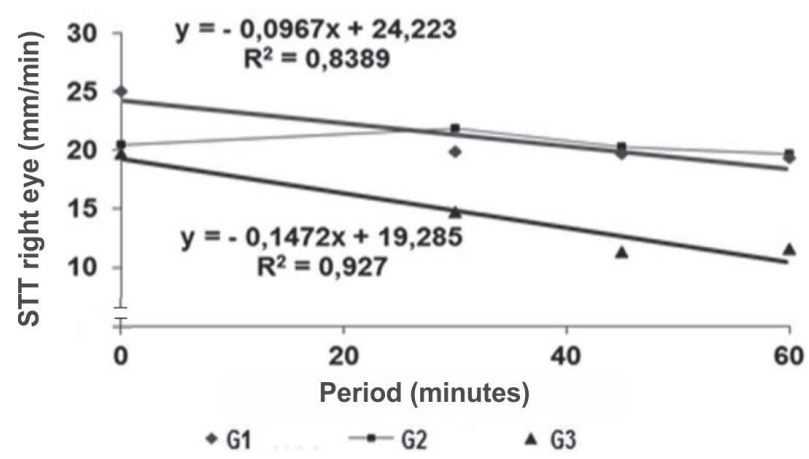

Figure 4. Decreasing linear effect on tear production of the right eye in G1 (acepromazine) and G3 (acepromazine + tramadol) with their respective equations over the experimental period. G2 (tramadol) showed no significant linear effect.

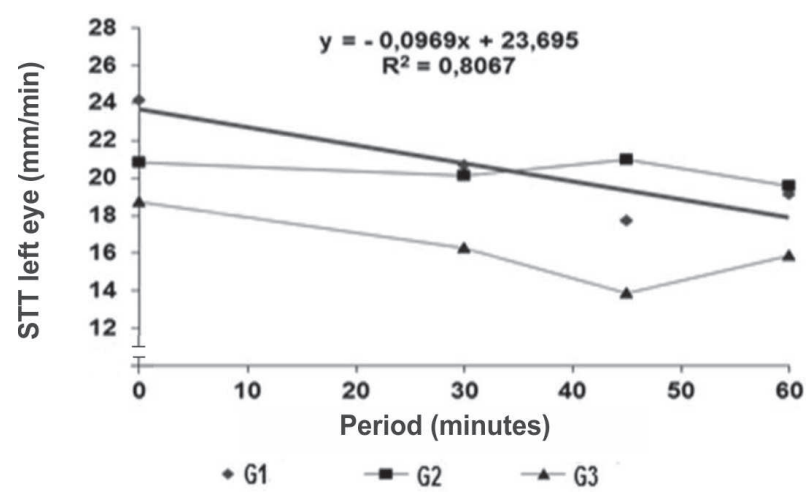

Figure 5. Decreasing linear effect on tear production of the left eye in G1 (acepromazine) with its respective equation over the experimental period. Groups G2 and G3 showed no significant linear effect.

Rev. Ceres, Viçosa, v. 60, n.2, p. 166-172, mar/abr, 2013
It can be inferred that there was reduction in tear production in both eyes of dogs in the groups that received acepromazine. However, its use alone caused greater tear reduction compared with the combined used with tramadol. These results corroborate those found by Ghaffari et al. (2010) in cats.

The administration of pre-anesthetic drugs induces the reduction of tear production (Simonazzi \& Zanichelli, 2002; Slatter, 2005b), but tramadol alone does not cause this effect.

Differences found between the left and right eyes can be attributed to increased exposure of the ocular surface of the eye right to pachymetry, with subsequent drying, Pontes et al. (2010) also observed differences in tear production between the eyes due to the greater exposure of the ocular surface of one of them.

The SBP and HR of the three groups showed no significant differences during the experimental period. According to Cortopassi \& Fantoni (2002) and Lemke (2007), the main hemodynamic effect of acepromazine is hypotension with compensatory tachycardia (Gross, 2003), resulting from blockage of peripheral $\alpha_{1}$-adrenergic receptors. The absence of hypotension can be attributed to dose and route of administration of acepromazine, because this effect is dose dependent and can reduce hypotension by $20-25 \%$ after intravenous administration (Cortopassi \& Fantoni, 2002; Lemke, 2007). As there was no hypotension, tachycardia consequently did not occur, since this effect is secondary to hypotension.

The group that received only the tramadol also showed no changes in SBP and HR, corroborating the findings of Parrilha et al. (2009).

It was found that the RR in G3 was lower than those of the other groups (Table 1). It decreased linearly in G1 and G3 from 0.1828 and $0.1797 \mathrm{mpm}$, respectively, every minute (Figure 6). Thus, the RR was reduced only in the groups that received acepromazine. This occurs by reducing the sensitivity of chemoreceptors to carbon dioxide after

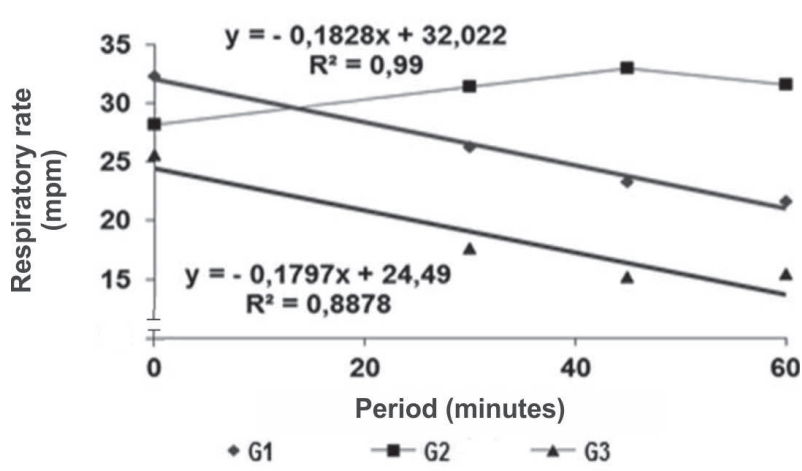

Figure 6. Decreasing linear effect on respiratory rate in G1 (acepromazine) and G3 (acepromazine + tramadol) with their respective equations over the experimental period. G2 (tramadol) showed no significant linear effect. 
administration of the drug (Cortopassi \& Fantoni, 2002; Gross, 2003; Lemke, 2007).

The tramadol acepromazine combination also reduced RR, corroborating the findings of Monteiro et al. (2009). However, the Tramadol alone was unable to change this parameter. Branson \& Gross (2003) and Duthie (2008) also found that tramadol promoted little respiratory depression.

The Rectal Temperature (RT) in G3 was lower than in the other groups (Table 1), with linear decrease of 0.0166 ${ }^{\circ} \mathrm{C}$ per minute (Figure 7). Thus, the group that received the combination of the two drugs showed little decrease in this parameter, corroborating the findings of Monteiro et al. (2009).

Alone, these drugs did not cause significant variations. However, Cortopassi \& Fantoni (2002), Gross (2003), Lemke (2007) and Monteiro et al. (2009) mentioned that it is common the occurrence of a slight decrease in the RT of animals receiving acepromazine. However, Parrilha $e t$ al. (2009) reported that the Tramadol does not change the thermoregulation parameter in dogs, as it occurred in this study.

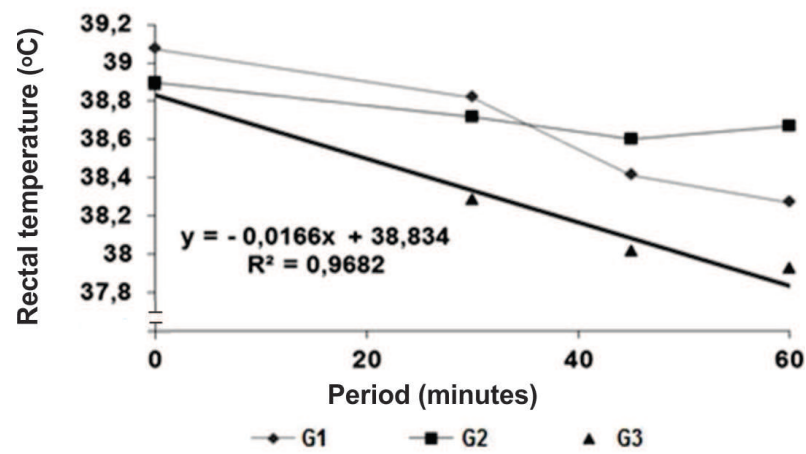

Figure 7. Decreasing linear effect on rectal temperature in G3 (acepromazine + tramadol) with its respective equation over the experimental period. Groups G1 and G2 showed no significant linear effect.

\section{CONCLUSIONS}

Tramadol is a pre-anesthetic medication, suitable for intraocular procedures that require the maintenance of the pupil diameter close to normal, excluding the effects of a general anesthetic in concomitant use. Furthermore, Tramadol alone proved to be unable to change tear production, the heart and respiratory rates, the systolic blood pressure and the rectal temperature in dogs.

Acepromazine causes miosis and is contraindicated for procedures that require pupil dilation. In addition, it reduces tear production and the respiratory rate.

Even when the two drugs are combined, some effects of acepromazine prevail over those observed with tramadol, such as inducing miosis and decreasing tear production, respiratory rate and rectal temperature in dogs. The use of acepromazine, alone or in combination with tramadol requires protection of the ocular surface from dryness to avoid unwanted ophthalmic changes.

\section{ACKNOWLEDGEMENTS}

The authors want to thank the Ophthalmos Pharmaceutical Industries Ltd and the College of Biological Sciences and Health FACISA / UNIVIÇOSA for their support.

\section{REFERENCES}

Almeida DE, Nishimori CT, Oriá AP, Paula DP, Nunes N \& Laus JL (2008) Effects of nitrous oxide on IOP and pupillary diameter in dogs anesthetized with varying concentrations of desflurane. Veterinary Ophthalmology, 11:170-176.

Bechara JN (2002) Anestesia em oftalmologia. In: Fantoni DT \& Cortopassi SRG (Eds.) Anestesia em cães e gatos. 1a ed. São Paulo, Roca. p.271-279.

Branson KR \& Gross ME (2003) Agonistas e antagonistas opioides. In: Adams HR (Ed.) Farmacologia e terapêutica em veterinária. $8^{\mathrm{a}}$ ed. Rio de Janeiro, Guanabara Koogan. p.224-248.

Brightman AH, Manning JP, Benson GJ \& Musselman EE (1983) Decreased tear production associated with general anesthesia in the horse. Journal of the American Veterinary Medical Association, 182:243-244.

Camacho AA \& Mucha CJ (2004) Semiologia do sistema circulatório de cães e gatos. In: Feitosa FLF (Ed.) Semiologia veterinária: A arte do diagnóstico. $2^{\mathrm{a}}$ ed. São Paulo, Roca. p.282-311.

Cortopassi SRG \& Fantoni DT (2002) Medicação pré-anestésica. In: Fantoni DT \& Cortopassi SRG (Eds.) Anestesia em cães e gatos. 1a ed. São Paulo, Roca. p.151-158.

Coulter DB \& Schmidt GM (1996) Sentidos especiais I: Visão. In: Swenson MJ \& Reece WO (Eds.) Fisiologia dos animais domésticos. 11 ${ }^{\mathrm{a}}$ ed. Rio de Janeiro, Guanabara Koogan. p.729-740.

Duthie DJR (2008) Remifentanil and tramadol. Brasilian Journal Anaesthesia, 81:51-57.

Feitosa FLF (2004) Exame físico geral ou de rotina. In: Feitosa FLF (ed.) Semiologia veterinária: A arte do diagnóstico. $2^{\mathrm{a}}$ ed. São Paulo: Roca. p.77-102, 2004.

Gelatt KN, Peiffer RL Jr, Erickson JL \& Gum GG (1975) Evaluation of tear formation in the dog, using a modification of the Schirmer tear test. Journal of the American Veterinary Medical Association, $166: 368-370$.

Ghaffari MS, Malmasi A \& Bokaie S (2010) Effect of acepromazine or xylazine on tear production as measured by Schirmer tear test in normal cats. Veterinary Ophthalmology, 13:1-3.

Gross ME (2003) Tranquilizantes, agonistas $\alpha^{2}$-adrenérgicos e agentes relacionados. In: Adams HR (Ed.) Farmacologia e terapêutica em veterinária. $8^{\mathrm{a}}$ ed. Rio de Janeiro, Guanabara Koogan. p.249-284.

Gross ME \& Giuliano EA (2007) Ocular patients. In: Tranquilli WJ, Thurmon JC \& Grimm KA (Eds.) Lumb \& Jones' veterinary anesthesia and analgesia. $4^{\mathrm{a}}$ ed. Iowa, Blackwell Publishing. p.943-954.

Herring IP, Pickett JP, Champagne ES \& Marini M (2000) Evaluation of aqueous tear production in dogs following general anesthesia. Journal of the American Animal Hospital Association, $36: 427-430$

Rev. Ceres, Viçosa, v. 60, n.2, p. 166-172, mar/abr, 2013 
Knaggs RD, Crighton IM, Cobby TF, Fletcher AJ \& Hobbs GJ (2004) The pupillary effects of intravenous morphine, codeine, and tramadol in volunteers. Anesthesia \& Analgesia, 99:108112

Krupin T, Cross DA \& Becker B (1977) Decreased basal tear production associated with general anesthesia. Archives of Ophthalmology, 95:107-108.

Lamont LA \& Mathews KA (2007) Opioids, nonsteroidal antiinflammatories, and analgesic adjuvants. In: Tranquilli WJ, Turmon JC \& Grimm KA (Eds.) Lumb \& Jones' veterinary anesthesia and analgesia. $4^{\mathrm{a}}$ ed. Iowa, Blackwell Publishing. p. 241-271

Laus JL, Galera PD, Souza MLB, Moraes A \& Andrade AL (1995) Standardization of the values of the "Schirmer tear test" modificated and of the "Schiotz tonometry indentation" from dogs of the region of Jaboticabal - SP - Brazil. Brazilian Journal of Veterinary Research and Animal Science, 32:173-176.

Lemke KA (2007) Anticholinergics and sedatives. In: Tranquilli WJ, Turmon JC \& Grimm KA (Eds.) Lumb \& Jones' veterinary anesthesia and analgesia. $4^{\mathrm{a}}$ ed. Iowa, Blackwell Publishing. p.203-239.

Moore CP (2003) Farmacologia oftálmica. In: Adams HR (Ed.) Farmacologia e terapêutica em veterinária. $8^{\mathrm{a}}$ ed. Rio de Janeiro, Guanabara Koogan. p.935-957.

Monteiro ER, Junior AR, Assis HM, Campagnol D \& Quitzan JG (2009) Comparative study on the sedative effects of morphine, methadone, butorphanol or tramadol, in combination with acepromazine, in dogs. Veterinary Anaesthesia and Analgesia, $36: 25-33$

Nikeghbali A, Falavarjani KG, Kheirkhah A, Bakhtiari P \& Kashkouli MB (2007) Pupil dilation with intracameral lidocaine during phacoemulsification. Journal of Cataract \& Refractive Surgery, 33:101-103.

Parrilha LR, Santos MV, Paolozzi RJ \& Cruz FS (2009) Avaliação dos parâmetros fisiológicos, analgésicos e neuroendócrinos utilizando diferentes doses de tramadol em cadelas submetidas à ovariosalpingohisterectomia. In: VI EPCC - Encontro Internacional de Produção Científica Cesumar. Centro Universitário de Maringá/ Paraná - Brasil. Avaiable at: < http://www.cesumar.br/ epcc2009/anais/leticia_rodrigues_parrilha.pdf $>$ Accessed in: March 10, 2013.
Pigatto JAT, Pereira FQ, Almeida ACVR, Redaeli R, Faganello CS \& Franzen AA (2007) Ceratoconjuntivite seca em cães e gatos. Acta Scientiae Veterinariae, 35:250-251.

Pontes KCS, Borges APB, Eleotério RB, Ferreira PS \& Duarte TS (2010) A comparison of the effects of propofol and thiopental on tear production in dogs. Revista Ceres, 57:757-761.

Saito A \& Kotani T (2001) Estimation of lacrimal level and testing methods on normal beagles. Veterinary Ophthalmology, 4:711

Simonazzi B \& Zanichelli S (2002) L'anestesia in oftalmologia veterinaria. Annali della Facolta di Medicina Veterina del Studi di Parma, 22:273-283.

Slatter D (2005a) Princípios da cirurgia oftálmica. In: Slatter D (Ed.) Fundamentos de oftalmologia veterinária. $3^{a}$ ed. São Paulo, Roca. p.135-157.

Slatter D (2005b) Sistema lacrimal. In: Slatter D (Ed.) Fundamentos de oftalmologia veterinária. $3^{a}$ ed. São Paulo, Roca. p.259281 .

Slatter D (2005c) Técnicas básicas de diagnóstico. In: Slatter D (Ed.) Fundamentos de oftalmologia veterinária. $3^{a}$ ed. São Paulo, Roca. p.97-134.

Slatter D \& Colitz CMH (2007) Princípios da cirurgia oftálmica. In: Slatter D (Ed.) Manual de cirurgia de pequenos animais, vol. 2., $3^{\text {a }}$ ed. São Paulo, Manole. p.1287-1288.

SAEG - Sistema para Análises Estatísticas e Genéticas (2007) Version 9.1. Viçosa, Fundação Arthur Bernardes, Universidade Federal de Viçosa. CD-ROM.

Wilkie DA (2007) Íris e corpo ciliar. In: Slatter D (Ed.) Manual de cirurgia de pequenos animais. vol. 2., $3^{\mathrm{a}}$ ed. São Paulo, Manole. p.1396-1401. 